\title{
The Relationship between Basic Education and Higher Education in a Pandemic Context: The Portuguese Situation
}

\author{
Maria José Sá, ${ }^{1}$ Sandro Serpa ${ }^{2}$
}

1. CIPES - Centre for Research in Higher Education Policies, 4450-227 Matosinhos, Portugal

2. University of the Azores, 9500-321 Ponta Delgada, Portugal

\begin{abstract}
In this article, the authors analyze the current situation in Portugal, in terms of the relationship between basic education and higher education, focusing on the influence of the COVID-19 pandemic in these processes. Moreover, this piece also addresses the quality of student preparation in basic education for a positive and successful experience in higher education.
\end{abstract}

Science Insights Education Frontiers 2021; 8(2):1029-1036.

Doi: 10.15354/sief.21.sc002

How to Cite: Sá, M.J., \& Serpa, S. (2021). Relationship between basic education and higher education in a pandemic context: The Portuguese situation. Science Insights Education Frontiers, 8(2):1029-1036.

Keywords: Basic Education, Higher Education, Portugal, COVID-19, Transition, Access to Higher Education

About the Author: Sandro Serpa, Ph.D., Department of Sociology, Faculty of Social and Human Sciences, University of the Azores; Interdisciplinary Centre of Social Sciences - CICS.UAc/CICS.NOVA.UAc; Interdisciplinary Centre for Childhood and Adolescence - NICA - UAc, Portugal. Email: sandro.nf.serpa@uac.pt

Correspondence to: Maria José Sá, Ph.D., CIPES - Centre for Research in Higher Education Policies, 4450-227 Matosinhos, Portugal.Email: mjsa@cipes.up.pt

Conflict of Interests: None. 


\section{Introduction}

$\mathrm{I}$

$\mathrm{N}$ this article, the current situation in Portugal is analyzed at the level of the relationship between basic education and higher education, focusing on the influence of the COVID-19 pandemic in these processes, based on the prerogative that schooling is currently critical in the advancement of any society and a fundamental human right (Serpa \& Sá, 2019). This commentary also questions to what extent, and in what way, basic and secondary education prepares students for higher education, namely in terms of equipping them with transversal skills, with digital skills taking on a leading role.

\section{The Transition from Basic Education to Higher Edu- cation in Portugal in the Pandemic Context}

Contextualizing this commentary, in Portugal, basic education encompasses 12 years, or until the student turns 18 years old. Once the student completes 12 years of basic and secondary education, he or she can enroll in higher education through a national competition covering mainland Portugal, as well as the Autonomous Regions of the Azores and Madeira.

Currently, the COVID-19 pandemic and its multiple social, economic and educational effects is an unavoidable and worrying issue (Carmo et al., 2020; Ferreira \& Serpa, 2021; Martins et al., 2021; Sá \& Serpa, 2020a; Serpa \& Ferreira, 2021), as well as their many and profound implications for the relationship between basic education and higher education (Sá \& Serpa, 2020b, 2020c). At the time of the writing of this commentary, the number of deaths caused by COVID-19 in Portugal, on March 12, 2021, and according to official data, was 16,650 individuals (General-Directorate for Health, 2021a).

There are variations between mainland Portugal and its two autonomous regions of the Azores and Madeira: specificities and differences in the measures taken, especially in terms of time (when they were taken) and with similar implications for the topic under analysis. For example, the President of the Regional Government of the Azores and, at the same time, President of the Conference of the Ultra-Peripheral Regions of the European Union asked the European Commissioner for Health and Food Safety, Stella Kyriakides, for a "direct intervention" with the European Commission to make vaccines available in numbers that allow the immunization of Azorean citizens:

(C) 2021 Insights Publisher. All rights reserved.

(c) (i) (2) Creative Commons Non Commercial CC BY-NC: This article is distributed under the terms of the Creative Commons Attribution-NonCommercial 4.0 License (http://www.creativecommons.org/licenses/by$\mathrm{nc} / 4.0 /$ ) which permits non-commercial use, reproduction and distribution of the work without further permission provided the original work is attributed by the Insights Publisher. 
[...] I do so as President of the Government of the Azores and, for this reason; I am primarily responsible for the destinies of the European citizens who live here. As you certainly know, the Azores, as well as the other ultra-peripheral regions, are spaces that are particularly vulnerable to phenomena of global scope due to the features that shape us and that find a concrete translation in the concept of the ultra-peripheral regions (LUSA, 2021).

Portugal has been preparing for a gradual relief of the lockdown as of March 15, which also covers the education system, with phased openings of the different levels of education that have been physically closed since January 22, 2021 (General-Directorate for Health, 2021b; Vieira, 2021). In these confinements, the Prime Minister, the Minister of Education and the Minister of Science, Technology and Higher Education recognized that the closure of schools and the inhibition of the face-to-face regime, either on basic education or higher education, would be a position only of last resort, taking into account the negative implications in the students' learning and, also, in the shaping of old and new inequalities (Cotrim, 2021; Silva, 2021).

In this context of progressive relief of the lockdown, and in a country where the rate of transition to higher education is not one of the highest (Dias, 2015; Domingos \& Baptista, 2018; Silva, 2021), with the economic factor playing a pivotal role, it is critical to ensure situations of justice and equity (Cherkaoui, 1999; Neves et al., 2016), as well as to mitigate current social inequalities in this new context (Borralho et al., 2020; Carmo et al., 2020; Ferreira \& Serpa, 2021), but also educational ones (Tavares \& Cândido, 2021). In this regard, Costa (2020) warns that

In the countries with the highest human development, in which Portugal is included, the impacts of the Covid-19 pandemic on the worsening of social inequalities have also been occurring in a very evident and very worrying way. In different social strata, there are situations of increased inequality and others are affected by new situations of inequality [...]. Another social category, school-age children and youth, has experienced difficulties in pursuing both school learning and peer socialization, both of which are critical to social growth paths. They are in educational inequality compared to previous generations and the physical and relational distance from schools further widens the inequalities between them - depending on the unequal educational and economic resources of their families. The inequalities in future opportunities between them have an increased gap (pp7 and pp8).

These measures motivated by the fight against the COVID-19 pandemic fostered the critical digitalization in higher education already in the near future (Carmo et al., 2020; Santos \& Serpa, 2017; Serpa \& Ferreira, 2018). As Lopes (2020) sustains, "In terms of technological fetishism and euphoria and the glorification of the internet of things', it is important to take into account people's internet, that is, the way they access it and how they appropriate it" (pp78), at least temporarily (Gaebel et al., 2021; Sá \& 
Serpa, 2020c). It would be interesting to consider this issue also in basic education (Costa et al., 2021).

In this process, the implementation of innovative pedagogical practices is vital, with the adoption of more active teaching-learning practices (Sá \& Serpa, 2018, 2020a). These authors (Sá \& Serpa, 2020c) advocate that "teachers and students, due to their traits and various reasons, will have to prepare for student-centered learning through the intentional and sensible mobilization of digital technologies in a complex process, in which each agent will be, ultimately, a critical content creator with enhanced digital literacy" (pp4520), which can and should be complemented with the promotion of home study strategies (General-Directorate for Education, 2021a). In terms of higher education, in particular, some examples of these innovative strategies are flipped teaching or participatory action research:

[...] the flipped teaching method. [...] this teaching model that reverses the sequence, starting from the student's autonomous work and concluding in the materialisation of the knowledge and competences attained, always with the teacher's support (Santos \& Serpa, 2020, pp169).

By fostering a direct engagement of those involved in solving problems or needs in a context of real situations, participatory action research (PAR) offers great potentialities for the academic training of future and even current professionals (Serpa et al., 2018, ppl).

Having analyzed the context of higher education in the present and near future, the question remains: does Portuguese basic and secondary education prepare and equip its students with skills and tools to smooth the transition from one educational level to the other?

The potential answer refers, naturally, to the analysis of curricular plans, pedagogical practices and co-curricular activities developed by basic and secondary schools, following the guidelines of the General-Directorate of Education (Decree-Law No. 139/2012 of July 5). To note, the National Curriculum document in force currently has been produced almost eight years ago.

As early as in the 1 st cycle (1st to 4th grade) there is a concern, albeit incipient, to provide students with basic knowledge of English. This subject is not part of the core curriculum; it is optional but is seen as a curriculum enhancement activity (GeneralDirectorate for Education, 2021b).

In the 2nd cycle (5th and 6th grade), Technological Education and the English Language are already mandatory components of the curriculum. This investment in more transversal and comprehensive areas is increased in the 3rd cycle (5th to 9th grade), with the integration in the curriculum of another foreign language (in addition to English) and the discipline of ICT (Information and Communication Technologies), with a workload similar to that of the so-called traditional subjects.

In secondary education (10th to 12 th grade), the focus on both technicalscientific and transversal competences is intensified, namely with the possibility for students to choose from among six major training areas. The areas of technology and 
languages have a very significant weight in the curricular plan of any of the choices, with the open purpose of preparing students for the enrolment and attendance of either higher education or professional/vocational study programs.

However, the COVID-19 pandemic caused profound changes and severe effects on the pedagogical practices themselves. According to Martins (2020), the unfeasibility of direct and face-to-face interaction between students and teachers, resulting from confinement measures and the consequent closure of educational establishments at all educational levels, abruptly interrupted the learning and teaching process without the possibility of preparing the actors for these new educational dynamics. In Portugal, schools reacted in a much diversified way to re-establishing contact with their students. Likewise, initiatives to resume the educational relationship and the teaching and learning process were also characterized by very distinct experiences. Such variability was visible in the implementation of distance learning, namely in its leadership (in many schools, it took on a clearly atomized nature, in which each teacher used a strategy or platform, whereas in others there was better coordination) and in the schools' communicative capacity (namely, in the contact with students and families).

\section{Conclusion}

The disruption in education caused by the lockdowns due to the COVID-19 pandemic further accentuated the inequalities and the lesser competences learned/apprehended, a concern that had already been raised in terms of the preparation for the transition from basic to higher education. Although the curricular plans include technological subjects, with a special focus on the 3rd cycle of basic education and secondary education, these plans were defined and structured for classroom teaching and are jeopardized in the presence of a pandemic that prevents or, at less, limits students in terms of interaction, which is very different in face-to-face teaching vis-a-vis distance learning.

Some of the more severe consequences and also challenges for higher education when welcoming new students are the following:

- Disruptive higher education;

- Receive particularly poorly-prepared students;

- Greater social and school inequalities, increasing social reproduction;

- Strategies to compensate for these limitations;

- Lower the level of requirement;

- Compensation classes;

- New competences and new ways of working;

- Acting as a "follow-up vehicle".

This situation has a profound impact in the short-term on students who are in transition, but also in the medium and long term, and which implies new recovery responses in basic education, but also in higher education. Despite the challenges and difficulties that this situation entails, it can be seen as a window of opportunity to change the cultural paradigm of each of these levels of education, to be seized. 
The education systems should learn from this experience, for which very few were prepared, and adapt their plans, methods and techniques to increasingly virtual learning and teaching processes, starting with the intentional preparation of students upstream of higher education and as early as possible, to equip students with the competences needed for a fruitful and successful experience in higher education, with a desirably, peaceful and smooth transition.

The coming years will, therefore, be critical in assessing the success of the implementation of distance learning in Portugal, the new paradigm towards which education systems, in general, are moving, in a country that is still poorly prepared, both in cultural and technological terms. While all the actors involved in the educational processes are working intensively towards achieving this goal, the results of their efforts are yet to be fully assessed.

\section{References}

Borralho, A., Palos, A.C., Diogo, F, Rocha, G. P.N., \& Serpa, S. (Coords). (2020). Desigualdades Sociais. Educação. Territórios [Social differences. Education. Territories]. Vila Nova de Famalicão: Húmus. ISBN: 978-989-755-491-9. [Portuguese]

Carmo, R.M., Tavares, I., \& Cândido, A.F. (2020). Um Olhar Sociológico sobre a Crise Covid-19 em Livro [A Sociological Stance at the Covid-19 Crisis in a Book]. Lisboa: Observatório das Desigualdades, CIESISCTE. [Portuguese] DOI: https://doi.org/10.15847/ciesod2020covid19

Cherkaoui, M. (1999). Sociologie de l'Éducation [Sociology of Education]. Paris: Presses Universitaires de France. ISBN: 978-213054-537-8. [French]

Costa, F.A. (2020). Desigualdades sociais e pandemia [Social inequalities and pandemic]. In R.M. Carmo, I. Tavares, \& A. F. Cândido (Eds.), Um Olhar Sociológico sobre a Crise Covid-19 em Livro [A sociological stance at the Covid-19 crisis in a book] (pp4-pp16). Lisboa: Observatório das Desigualdades,
CIES-ISCTE. [Portuguese] DOI: https://doi.org/10.15847/ciesod2020covid19

Costa, F.A., Auxtero, M.D., Martins, A.P., \& Caramona, M.M. (2020). An overview of Portugal's educational challenges and responses to the global pandemic of COVID19. Pharmacy Education, 20(2):98-101. DOI: https://doi.org/10.46542/pe.2020.202.98101

Cotrim, A. (2021). Covid-19. Ministro rejeita para já alterar aulas ou avaliações presenciais no ensino superior [Covid-19. Minister rejects for now changing classes or face-to-face assessments in higher education]. Agência Lusa, 19 de janeiro. [Portuguese] https://observador.pt/2021/01/19/covid-19ministro-rejeita-para-ja-alterar-aulas-ouavaliacoes-presenciais-no-ensino-superior/

Dias, D. (2015). Has massification of higher education led to more equity? Clues to a reflection on Portuguese education arena. International Journal of Inclusive Education, 19(2):103-120. DOI:

https://doi.org/10.1080/13603116.2013.7882 $\underline{21}$ 
Domingos, A., \& Baptista, J.O. (2018).

Transição entre o Ensino Secundário e o Ensino Superior: 2015/16 - 2016/17 [Transition from secondary to higher education: 2015/16-2016/17]. Lisboa: DirectorateGeneral for Education and Science Statistics. [Portuguese]

Serpa, S., \& Ferreira, C. (2018). Society 5.0 and social development: Contributions to a discussion. Management and Organizational Studies, 5(4):26-31. DOI: https://doi.org/10.5430/mos.v5n4p26

Ferreira, C.M., \& Serpa, S. (Eds.) (2021). COVID-19 and Social Sciences. Basel: MDPI. DOI:

https://doi.org/10.3390/books978-3-03650155-0

General-Directorate for Education (2021a). Estudo em Casa [Study at home]. [Portuguese] https://estudoemcasa.dge.mec.pt/

General-Directorate for Education (2021b). Currículo Nacional - DL 139/2012 [National Curriculum - DL 139/2012]. [Portuguese] http://www.dge.mec.pt/curriculo-nacionaldl-1392012

General-Directorate for Health (2021a). Ponto de Situação Atual em Portugal [Current Situation in Portugal]. [Portuguese] https://covid19.min-saude.pt/ponto-desituacao-atual-em-portugal/

General-Directorate for Health (2021b). Governo revela plano de reabertura gradual até 3 de maio [Government reveals plan for gradual reopening until May 3]. [Portuguese] https://covid19.min-saude.pt/governo$\underline{\text { revela-plano-de-reabertura-gradual-ate-3-de- }}$ maio/

Gaebel, M., Zhang, T., Stoeber, H. \& Morrisroe, A. (2021). Digitally Enhanced Learning and Teaching in European Higher Education Institutions. European University Association absl.

https://eua.eu/downloads/publications/digihe\%20survey\%20report.pdf

Lopes. J.T. (2020). Elogio da co-presença no ensino superior: Breves notas [Praise for copresence in higher education: Brief notes]. In R. M. Carmo, I. Tavares, \& A. F. Cândido (Eds.), Um Olhar Sociológico sobre a Crise Covid-19 em Livro [A Sociological Stance at the Covid-19 Crisis in a Book] (pp78pp82). Lisboa: Observatório das Desigualdades, CIES-ISCTE. [Portuguese] DOI:

https://doi.org/10.15847/ciesod2020covid19

LUSA (12-03-2021). Covid-19: Governo dos

Açores pede à Comissão Europeia

imunização dos açorianos [Covid-19: Government of the Azores asks the European Commission to immunize the Azoreans]. RTP News. 2021-03-12. [Por-tuguese] https://www.saudemais.tv/noticia/30040covid-19-governo-dos-acores-pede-acomissao-europeia-imunizacao-dosacorianos

Martins, S.C. (2020). A educação e a Covid-19: Desigualdades, experiências e impactos de uma pandemia não anunciada [Education and Covid-19: Inequalities, experiences and impacts of an unannounced pandemic]. In R.M. Carmo, I. Tavares, \& A.F. Cândido (Eds.), Um Olhar Sociológico sobre a Crise Covid-19 em Livro [A Sociological Stance at the Covid-19 Crisis in a Book] (pp37pp55). Lisboa: Observatório das Desigualdades, CIES-ISCTE. [Portuguese] DOI:

https://doi.org/10.15847/ciesod2020covid19

Martins, J.G., Ferreira, C.M., \& Serpa, S. (2021). Interdependencies between COVID-19, mental illness and living uneasiness. Academic Journal of Interdisciplinary Studies, 10(1):1. DOI: https://doi.org/10.36941/ajis2021-0001

Neves, T., Ferraz, H., \& Nata, G. (2016). Social inequality in access to higher education: Grade inflation in private schools and the ineffectiveness of compensatory education. International Studies in Sociology of Education, 26(2):190-210. DOI:

https://doi.org/10.1080/09620214.2016.1191 966

Sá, M.J., \& Serpa, S. (2020a). The COVID-19 pandemic as an opportunity to foster the sustainable development of teaching in higher education. Sustainability, 12(20):8525. DOI: https://doi.org/10.3390/su12208525

Sá, M.J., \& Serpa, S. (2020b). The global crisis brought about by SARS-CoV-2 and its impacts on education: An overview of the Por- 
tuguese panorama. Science Insights Education Frontiers, 5(2):525-530. DOI: https://doi.org/10.15354/sief.20.ar039

Sá, M.J., \& Serpa, S. (2020c). COVID-19 and the promotion of digital competences in education. Universal Journal of Educational Research, 8(10):4520-4528. DOI: https://doi.org/10.13189/ujer.2020.081020

Sá, M.J., \& Serpa, S. (2018). Transversal competences: Their importance and learning processes by higher education students. $E d$ ucation Sciences, 8(3):126. DOI: https://doi.org/10.3390/educsci8030126

Santos, A.I., \& Serpa, S. (2020). Flipped classroom for an active learning. Journal of Education and E-Learning Research, 7(2):167173. DOI:

https://doi.org/10.20448/journal.509.2020.72 $\underline{.167 .173}$

Santos, A.I., \& Serpa, S. (2017). The importance of promoting digital literacy in higher education. International Journal of Social Science Studies, 5(6):90. DOI: https://doi.org/10.11114/ijsss.v5i6.2330

Serpa, S., \& Ferreira, C.M. (2021). COVID-19 and stigmatisation processes. Journal of Educational and Social Research, 11(2):5. DOI: https://doi.org/10.36941/jesr-2021-0025

Serpa, S., Ferreira, C.M., Santos, A.I., \& Teixeira, R. (2018). Participatory action research in higher education training. International Journal of Social Science Studies, 6(6):1-7. DOI: https://doi.org/10.11114/ijsss.v6i6.3286

Serpa, S., \& Sá, M. (2019). Sociology of education for a sustainable future. Sustainability, 11(6):1757. DOI: https://doi.org/10.3390/su11061757
Silva, C.D. (2021). Education and Training in Portugal. Lisboa: Directorate-General for Education and Science Statistics (DGEEC) and Ministry of Education and Ministry of Science, Technology and Higher Education. https://www.dgeec.mec.pt/np4/\%7B \$clientS ervletPath\%7D/?newsId=1215\&fileName $=$ P resentationPPUE_EN.pdf

Silva, S. (2021). "Custo do encerramento das escolas é bem superior ao risco", argumenta ministro da Educação ["The cost of closing schools is much higher than the risk", argues Minister of Education]. Newspaper Público, January 12. [Portuguese] https://www.publico.pt/2021/01/12/sociedad e/noticia/custo-encerramento-escolas-bemsuperior-risco-argumenta-ministroeducacao-1946041

Vieira, R.S. (12-03-2021). Datas, testes e vacinação. 10 perguntas e respostas sobre o regresso à escola [Dates, tests and vaccination. 10 questions and answers about the return to school]. SAPO24. [Portuguese] https://24.sapo.pt/atualidade/artigos/datastestes-e-vacinacao-10-perguntas-e-respostassobre-o-regresso-a-escola

Tavares, I. \& Cândido, A.F. (2020). Balanço e perspetivas de futuro: O impacto da Covid19 e a (re)produção das desigualdades sociais [Balance and perspectives for the future: The impact of Covid-19 and the (re)production of social inequalities]. R.M. Carmo, I. Tavares, \& A.F. Cândido (Eds.), Um Olhar Sociológico sobre a Crise Covid19 em Livro [A Sociological Stance at the Covid-19 Crisis in a Book] (pp. 244-256). Lisboa: Observatório das Desigualdades, CIES-ISCTE. DOI: https://doi.org/10.15847/ciesod2020covid19 